\title{
8 The development of the Chinese film industry in 2018
}

\author{
Shuzhen Sun
}

The year 2018 was the 40th anniversary of China's Reform and Open Door policy. In light of the new era and spirit of the 19th Party Congress of China, 2018 was the first year for the Chinese film industry to thoroughly incorporate the socialist ideology with Chinese characteristics into its filmmaking practice. This is the key to implementing the 13th Five-Year Plan to achieve an overall prosperous society. The year of 2018 was also the beginning of the unified management of film work by the Central Publicity Department. To standardize and support the development of the film industry, the Central Committee of the Party and the State Council successively issued a series of film industry policies and measures in 2018. Along with an improvement in the audience's consumption level and the change of the consumption concept, the broad market and good consumption foundation further contributed to the development of the quality and quantity of Chinese film productions (Table 8.1).

\section{Analysis of the environment of China's film industry in 2018}

\section{The policy environment of the Chinese film industry}

In 2018, the Chinese film industry reform continued. The Notice on Further Regulating the Taxation Order of the Film and Television Industry, and the Opinions on Accelerating the Construction of Cinemas to Promote the Prosperity and Development of the Film Market and other film policies and regulations were introduced, one after another, resulting in the swift development of the film industry in China.

In recent years, on the one hand, the Chinese film industry has developed rapidly, and its growth momentum is strong. On the other, there are also problems, such as high salaries for stars, faked contracts and tax evasion. These problems not only lead to high virtual program costs, but also undermine a healthy filmmaking environment. At the same time, the problems above tend to mislead young people to blindly worship film stars.

In June 2018, the Publicity Department of the CPC Central Committee, the State Administration of Taxation, the National Radio and Television 
Table 8.1 Main indicators of the development of China's film industry, 2012-2018

\begin{tabular}{|c|c|c|c|c|c|c|c|}
\hline Classification & 2012 & 2013 & 2014 & 2015 & 2016 & 2017 & 2018 \\
\hline $\begin{array}{l}\text { Box office (100 million } \\
\text { yuan) }\end{array}$ & 166 & 215 & 294 & 439 & 455 & 558 & 607 \\
\hline Cinema (line) & 45 & 45 & 47 & 48 & 48 & 48 & 48 \\
\hline $\begin{array}{l}\text { Number of screens } \\
\text { (block) }\end{array}$ & 13118 & 18195 & 23592 & 31627 & 41179 & 50776 & 60079 \\
\hline Number of theatres & 3062 & 3879 & 4926 & 6500 & 7912 & 9342 & 10485 \\
\hline $\begin{array}{l}\text { Viewing people ( } 100 \\
\text { million person-time) }\end{array}$ & 4.66 & 6.17 & 8.34 & 12.6 & 13.72 & 16.2 & 17.17 \\
\hline Average fare (yuan) & 36.3 & 35.3 & 35.5 & 35.0 & 33.1 & 34.4 & 35.5 \\
\hline $\begin{array}{l}\text { The number of feature } \\
\text { films produced (part) }\end{array}$ & 745 & 638 & 618 & 686 & 772 & 798 & 902 \\
\hline
\end{tabular}

Source: EN Film Think Tank.

Administration, the Ministry of Culture and Tourism, and the National Film Board jointly issued a notice on the management of the film industry's sky-high fees, faked contracts and tax evasion. The Notice stressed that it is necessary to formulate standards for the implementation of film and television program payment schemes, and clarify the maximum pay limit for actors and program guests; all film and television production companies and TV stations must strictly implement the total pay for all actors and guests, and must not exceed the total production budget of each film or TV series, and network audiovisual programs. The total payment for all actors/ actresses of a film project cannot exceed 40 percent of the production cost, and the payment for the star actors/actress cannot exceed 70 percent of the total fee for all actors/actresses of a film project. Besides, the relevant department of film and television should strengthen supervision over the participation of film and television stars in entertainment programs and reality shows, with measures to counter possible tax evasion by stars. The Notice requests the supervisory department to strengthen the education of film professionals to put social benefits first and create a healthy environment for the film industry.

In October 2018, in order to further strengthen tax supervision, the State Administration of Taxation issued The Notice on Further Regulating the Taxation Order of the Film and Television Industry. The Notice stipulates that all film and television production companies, star studios and other enterprises and employees must undergo a tax review dating back to 2016. Any company and related film professionals who legally go through the tax review and pay taxes back, if there is any pending tax before 2019, will be exempt from legal prosecution and penalties.

By strengthening the film and television industry's taxation, the Chinese government has effectively regulated tax collection and further protected the legitimate rights and interests of taxpayers according to the law, thus achieving 
the goal of maintaining a fair competitive tax environment and promoting the healthy development of the film industry.

On December 13, 2018, in order to promote the rapid development of the number of cinemas, the National Film Board issued the Opinions on Accelerating the Construction of Cinemas to Promote the Prosperity of the Film Market. According to the Opinions: (1) the total number of cinema screens will total more than 80,000 by 2020 . The distribution of cinemas and screens will be more closely matched to the level of urban development and population distribution; (2) advanced screening technology and facilities are to be used in upgrading cinema construction; (3) the construction of countylevel urban cinemas and township cinemas is to be encouraged; and (4) further reforms are to be applied to the Chinese cinema system with a focus on different characteristics of different cinema chains. The introduction of the Opinions will help balance the distribution of cinema resources in the central and western regions of China, coordinate the development of urban and rural areas, and provide solid policy support for the realization of strong film industry in the provinces.

\section{The economic environment of the Chinese film industry}

In 2018, China's economy progressed steadily with a positive trend of quality improvement and structural optimization. The main improvements are as follows: (1) the employment target of 11 million new jobs is completed three months ahead of the target deadline; (2) the willingness to invest in the private sector continued to increase; (3) the proportion of manufacturing investment increased substantially, and structural investment was gradually optimized; (4) the overheating of the real estate market has been eased. On the other hand, China's economy has been steadily changing. Due to factors such as an accumulation of household debt pressure, the widening gap between the rich and the poor, and the increased trade friction between China and the United States, a number of problems emerged, such as the continuous decline in consumer spending, difficulties in operating some enterprises, and declining market vigor. At the same time, the international economic environment has undergone tremendous changes, and there have been unfavorable situations, such as the slowdown in global economic growth, the prevalence of trade protectionism, the volatility of the RMB exchange rate, and the slight decline in foreign exchange reserves.

In 2018, the annual gross domestic product (GDP) was 900.30 billion yuan, which is an increase of 6.6 percent over 2017, achieving an expected development target of around 6.5 percent (Figure 8.1). China's economic growth ranks first among the world's top five economies, and its contribution to world economic growth is close to 30 percent. In 2018, China's macroeconomy faced a complex and ever-changing external environment, but it still achieved good results mainly in the following aspects: (1) high-quality development led to remarkable results; (2) supply-side structural reforms are well 


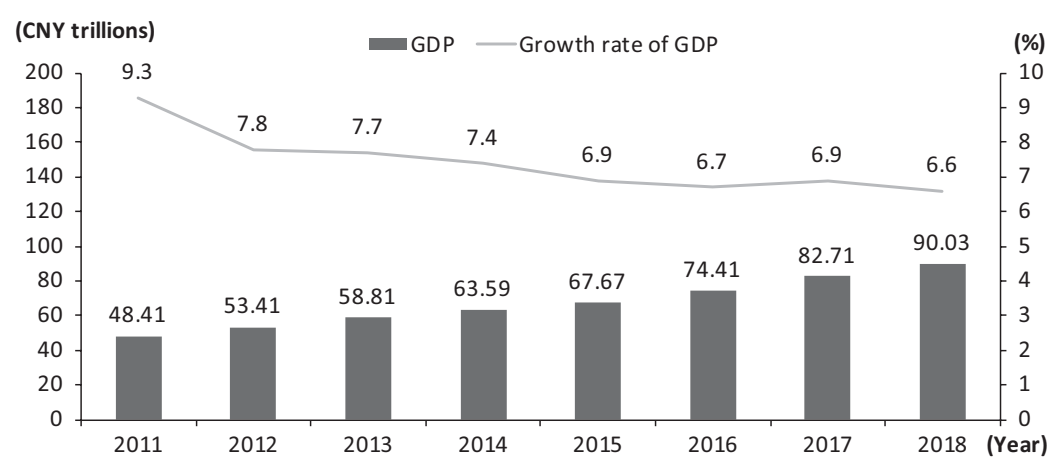

Figure 8.1 China's GDP and growth rate, 2011-2018.

advanced; (3) the initial achievements were made in a tough economic situation; (4) the Reform and Open Door policy has been continuedly practiced and enhanced; (5) China took proper measures to react to the Sino-US trade friction; and (6) overall the Chinese people's social and economic conditions improved.

The transformation of policy norms and concepts has injected a strong impetus into the sound development of Chinese films. The film industry in 2018 is still at a high-speed development stage. As the investment (especially investment from Internet platforms) gradually flows into the film industry, the industrial model of the film industry chain continues to undergo subtle changes. Based on the amount of investment, the competition in Chinese film industry has gradually extended to both ends of the industrial chain and is no longer concentrated in the traditional investment channels and fields of the film industry chain.

In the future, the Chinese film investment and financing market will present the following characteristics: (1) the film capital investment hotspot will be focused on deepening the commercial value of high-quality Internet Protocols (IP); (2) the next stage of film investment will affect legal services, financial services, ticketing systems, special effects production, artists brokerage and other film-related services; and (3) large amounts of capital continue to be invested in the entire film industry chain.

\section{The social environment of the Chinese film industry}

The demographics of the Chinese population are divided into three types based on the categorization of ages: 0-14 years old; $15-64$ years old; 65 years old and above. At present, China's population is aging fast, which leads to many social problems, such as a reduction in demographic dividends, a shortage of labor, and an imbalance between men and women. In order to solve these social problems, China has implemented the "Comprehensive Second Child" 
policy since 2016. Based on this policy, the experts foresee that although the current policy effects have not yet become obvious, in the future, the total population of China will remain stable and the structure of the population will mostly be balanced. This is undoubtedly a good factor in maintaining and increasing the size of the existing Chinese film market.

The consumption structure of Chinese residents consists of both material consumption and spiritual consumption. The upgrading of the consumption structure means that in total consumption, the proportion of service consumption and innovative goods consumption has gradually increased. Since the Reform and Open Door policy, China has experienced three upgrades in its consumption structure. The third phase of the current consumer structure upgrade is mainly due to the rapid growth of the IT industry, the real estate industry, the automotive industry and the cultural industry. With the upgrading of the consumption structure, the consumer's consumption focus shifts, and the proportion of service consumption in the consumption structure is increasing. Undoubtedly, the upgrading of the consumption structure will open up a new window for the development of the Chinese film industry.

\section{The network technology environment of the Chinese film industry}

Since the release of The Promoting Internet Protocol Version 6 (IPv6) Scale Deployment Action Plan in November 2017, Chinese operators have initially had the ability to support IPv6 over the network and are now moving from network capabilities to application adoption. China's international export bandwidth is $8826302 \mathrm{Mbps}$, with a half-year growth rate of 20.6 percent. The Chinese Internet users now have faster Internet access, better cross-border roaming calls and better network quality. In 2018, the proportion of Internet penetration and mobile Internet users in China continued to increase. Figure 8.2 shows that from June 2013 to June 2018, the number of Chinese

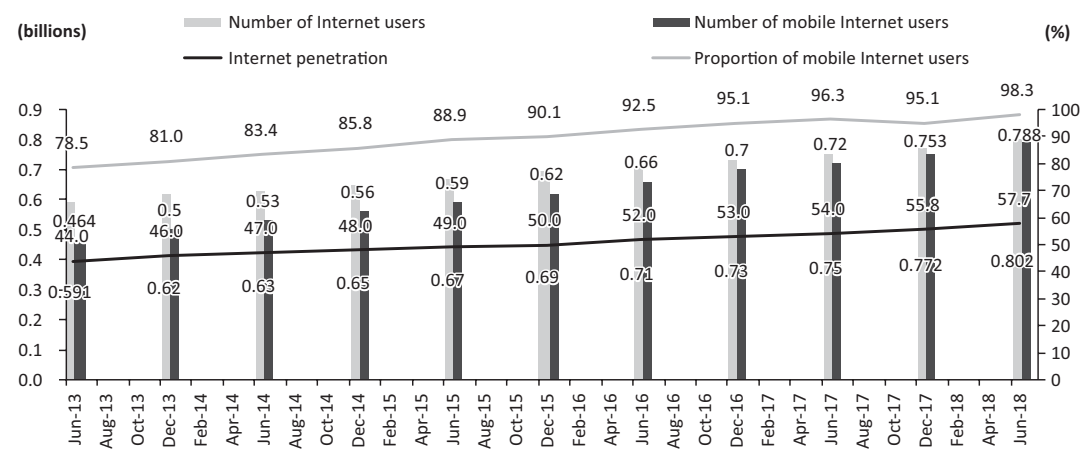

Figure 8.2 Scale and proportion of Internet users and mobile Internet users, June 2013-June 2018. 
netizens increased from 590 million to 800 million, and the Internet penetration rate increased from 44 percent to 58 percent. As of June 2018, the number of video users was 594 million, accounting for 74 percent of the total Internet users. Among the total number of netizens, the number of mobile Internet users increased from 460 million to 790 million, and the proportion of mobile netizens to all netizens increased from 78 percent to 99 percent. In June 2018, the number of mobile video users reached 580 million, accounting for 73.4 percent of the total number of mobile Internet users. The growth rate of mobile video users is much higher than the overall growth rate of mobile Internet users. The rapid increase in video users, especially mobile video users, is the inevitable result of strong demand in the online entertainment market.

\section{Box office analysis of the Chinese film industry, 2018}

The Chinese film industry has maintained its momentum of rapid development. The annual domestic box office has increased from 6.3 billion yuan in 2009 to 60.07 billion yuan in 2018, with a compound growth rate of 28.62 percent. In 2018, the box office proportion of domestically produced films was 60.3 percent which is an increase of 6.2 percentage points from 2017. The number of cinema admissions increased from 200 million in 2009 to 1.72 billion in 2018, with a compound growth rate of 27.01 percent. According to the above statistics, Chinese film industry's box office has achieved rapid growth, and its status as the world's second largest film market has been further consolidated.

\section{Analysis of the annual total box office of Chinese films in 2018}

In 2018, the annual box office of Chinese films exceeded 60 billion yuan as a new box office record after 2017. From 2011 to 2018, the annual box office of Chinese films was respectively 13.1 billion yuan, 16.6 billion yuan, 21.5 billion yuan, 29.4 billion yuan, 43.9 billion yuan, 45.5 billion yuan, 55.8 billion yuan and 60.7 billion yuan, with respective growth rates of 29 percent, 27 percent, 30 percent, 37 percent, 49 percent, 4 percent, 23 percent and 9 percent (Figure 8.3). In 2018, the annual box office growth rate of Chinese movies was less than 10 percent, which means that the domestic film market is gradually returning to a rational environment, and the box office structure is continuously improving. However, compared to the box office growth rate of 7 percent in the North American film market in 2018, the Chinese film market still has considerable potential, and the box office gap with the North American film market has been gradually reduced.

\section{Monthly box office analysis in 2018}

Compared with the monthly box office in 2017, the box office growth rate was positive in the first six months in 2018, and the next six-month box office 


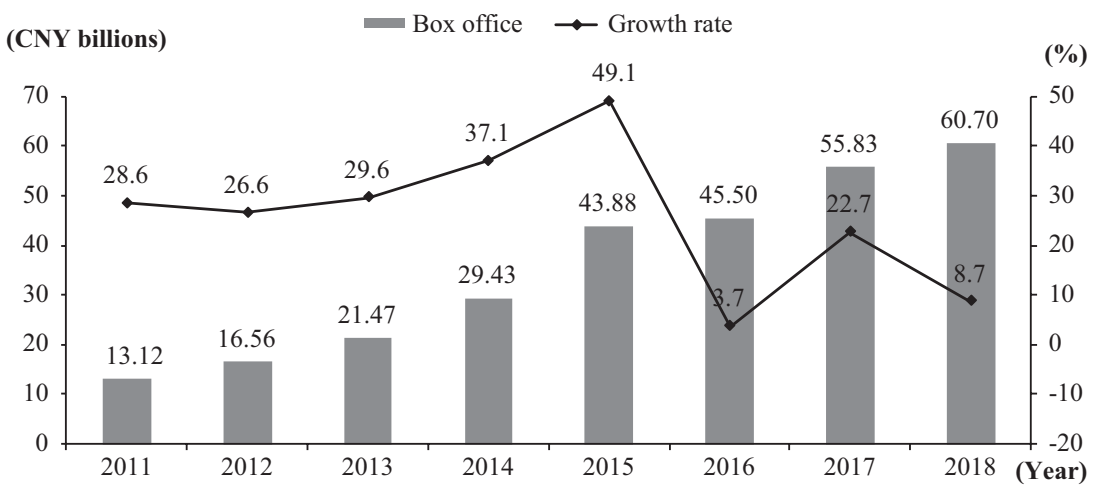

Figure 8.3 Annual box office and growth rate of Chinese films, 2011-2018.

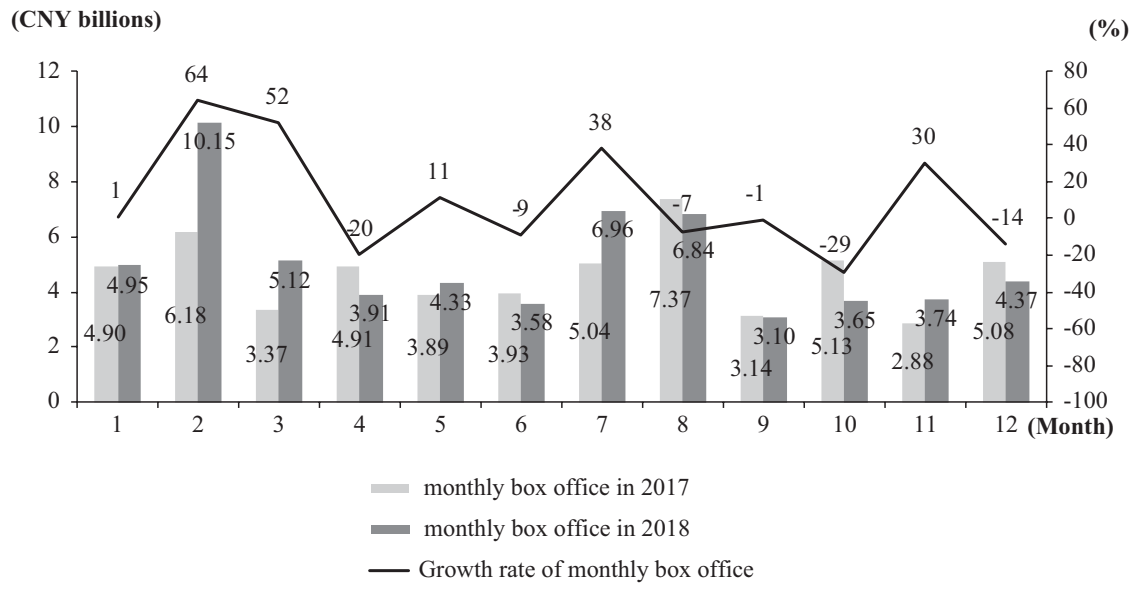

Figure 8.4 Monthly box office analysis for 2017 and 2018.

growth rate was negative. The monthly box office in January and September was basically the same as that of 2017 in the same monthly period. Box office declines occurred in April, June, August, September, October and December. Judging by four months in the second half of the year, the decline indicates that the monthly box office performance in the second half of the year was not as high as the previous six months (Figure 8.4).

In the first quarter of 2018, the box office performance was outstanding, achieving a daily increase in the box office on three consecutive days and a record of over 10 billion yuan in a single-month box office (with a box office 
of 10.1 billion yuan in February). In February and March 2018, the total box office growth was 5.6 billion yuan, while the box office growth in 2018 was 4.9 billion yuan. The box office of the year mainly came from February and March.

In April 2018, the box office fell by nearly 1 billion yuan compared to that of the same period of the previous year. The main reason was that no new film in the Fast \& Furious series was released. The monthly box office in 2015 and April 2017 increased on a yearly basis, but the monthly box office in April 2016 decreased. It is closely related to the release of Fast \& Furious. The annual box office champion is the imported film Avengers: Infinity War which was released in May and increased the box office of the month by 400 million yuan. The box office in June fell by 300 million yuan, mainly because of the shortage of blockbusters.

In July, the box office rose by 2 billion yuan compared to that of the same period of the previous year, mainly because of the release of Dying to Survive (the month's box office of 3.056 billion yuan) and Hello Mr. Billionaire (the month's box office of 1.29 billion yuan). In August, the box office fell by 600 million yuan compared to that of the same period of the previous year. The main reason was that Wolf Warriors 2 was released in August 2017, and the box office achieved 4.44 billion yuan in the same month. In September, the box office was basically the same compared to that of the same period of the previous year.

In October, the box office fell by 1.5 billion yuan compared to that of the same period of the previous year, which was the best month for the box office in 2018. The main reason was the fiasco of the National Day season. Also, the Ma Hua Comedy Hello, Mrs. Money, which was released during the National Day holiday week, achieved 1.44 billion yuan which is less than the box office of Never Say Die in 2017. In November, the box office rose by 800 million yuan compared to that of the same period of the previous year, mainly due to the imported Hollywood film Venom, which contributed 1.74 billion yuan to the box office and became the black horse of the box office. In December, the box office fell by 700 million yuan compared to that of the same period of the previous year mainly because of the weak performance of the national films, which should have been the main force of the Lunar New Year.

\section{Analysis of the box office contribution of domestic and imported films}

From 2011 to 2018, the annual box office of domestic films was respectively 7 billion yuan, 8 billion yuan, 13.4 billion yuan, 18.5 billion yuan, 28.5 billion yuan, 26.8 billion yuan, and 30.2 billion yuan, or 36.6 billion yuan, respectively accounting for 54 percent, 48 percent, 63 percent, 63 percent, 65 percent, 59 percent, 54 percent, 60 percent; and imported box office outlets were respectively 6.1 billion yuan, 8.6 billion yuan, 8.1 billion yuan, 10.9 billion yuan, 15.4 billion yuan, and 18.7 billion yuan, 25.6 billion yuan, and 24.1 billion yuan, respectively accounting for 46 percent, 52 percent, 37 percent, 
(CNY billions)

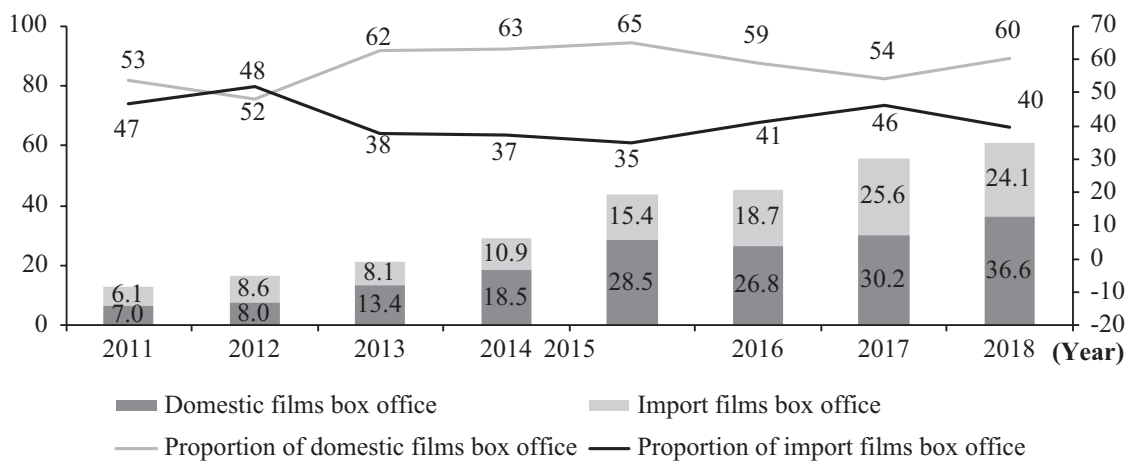

Figure 8.5 Box office analysis of domestic films and imported films, 2011-2018.

37 percent, 35 percent, 41 percent, 46 percent, 40 percent (Figure 8.5). Against the strong competition from Hollywood blockbusters, domestic filmmakers have tried to figure out the demand of Chinese audiences, and Chinese films are becoming more competitive at the box office. Since 2013, despite the box office's up and downs, the proportion of box office of domestic films has always been higher than that of imported films. In 2018, the box office of domestic films was 1.52 times the box office of imported films,' and domestic films have become the core driving force for the growth of the box office in China. The number of imported films in 2018 is higher than that in 2017, and the main reasons for the poor box office of imported films are: (1) most imported films are similar to other previously imported films, hence they present no surprise and attraction to domestic audiences; and (2) the average box office has declined.

From the top ten box office films released in 2018, the total box office was 24.13 billion yuan, accounting for 39.8 percent of the total box office of the year. Of the top ten films in the box office, domestic and imported films accounted for five each, and domestically produced ticket houses accounted for 14.93 billion yuan, accounting for 61.9 percent. The domestic box office appeal was higher than that of the imported blockbusters. Four of the top five films in the box office are domestic films, namely Operation Red Sea (3.651 billion yuan), Detective Chinatown II (3.398 billion yuan), Dying to Survive (3.1 billion yuan) and Hello Mr. Billionaire (2.548 billion yuan).

\section{Annual box office analysis of a single film of more than 100 million yuan}

In 2018, in the Chinese film market, there were 86 films with a box office of more than 100 million yuan, excluding The Ex-File: The Return of the Exes, Youth, Hanson and the Beast, and Demon Bell released in 2017. The newly 


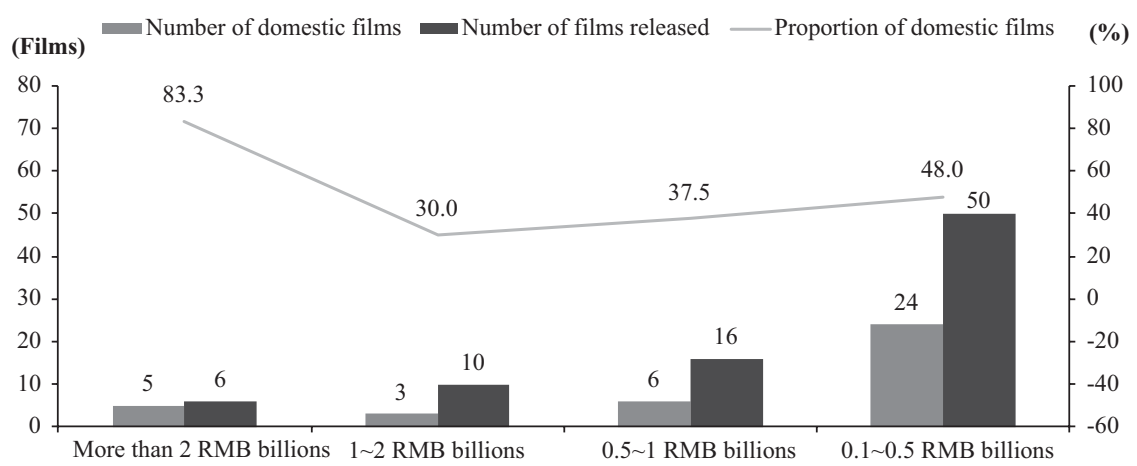

Figure 8.6 Number of films released with a budget of over 100 million yuan at the box office in 2018.

released box office has over 82 million films in 2018: 43 domestically produced films and 39 imported films. Among the six films that passed the annual box office of over 2 billion yuan, there were five Chinese films, accounting for 83.3 percent, namely Operation Red Sea (3.651 billion yuan), Detective Chinatown II (3.398 billion yuan), Dying to Survive (3.1 billion yuan), Hello Mr. Billionaire (2.548 billion yuan), and Monster Hunt 2 (2.237 billion yuan). Of the 39 imported films, Avengers: Infinity War topped the list with 2.391 billion yuan, while Venom (1.871 billion yuan) and Aquaman (1.852 billion yuan) ranked in 2 nd and 3 rd place.

In 2018, ten films generated 1-2 billion yuan at the annual box office, three of which were domestically produced films, accounting for 30 percent. Some 16 films generated 510 million yuan to 1 billion yuan at the annual box office, including 11 domestic films, accounting for 68.8 percent. Some 50 films generated 100-500 million yuan at the annual box office, including 24 domestic films, accounting for 48.0 percent (Figure 8.6). Based on the above statistics, the films in the high-end box office segment of more than 2 billion yuan all were of high production quality.

In 2018, the annual box office for the films that achieved box office of more than 2 billion yuan was 17.3 billion yuan, of which the domestic box office in China was 14.9 billion yuan, accounting for 86 percent. The annual box office for the films achieving box office of 1.01-2 billion yuan totaled 14.1 billion yuan, and the domestic box office in China was 4 billion yuan, accounting for 28 percent. The annual box office for the films achieving box office of 510 million to 1 billion yuan was 10.8 billion yuan, and the domestic box office in China was 7.3 billion yuan, accounting for 68 percent. The annual box office for the films achieving box office of 100-500 million yuan was 11.3 billion yuan, and the domestic box office in China was 5.4 billion yuan, accounting for 48 percent (Figure 8.7). 
Box office of domestic films $\longrightarrow$ Box office of films released - Proportion of domestic films (CNY billions)

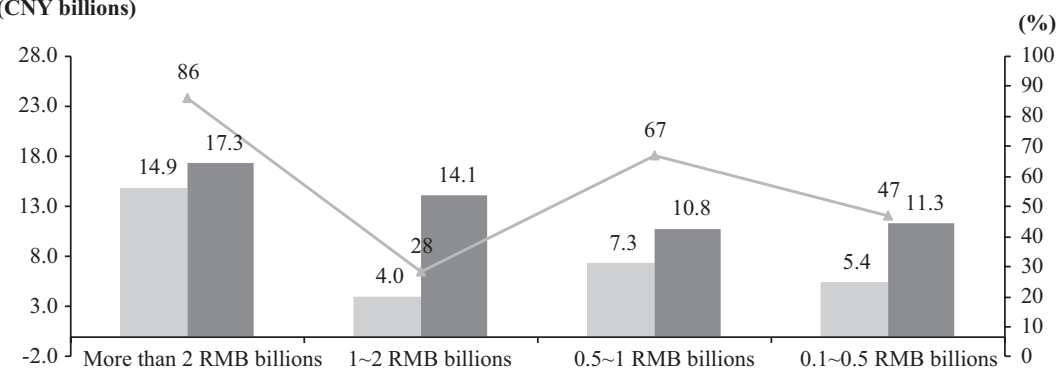

Figure 8.7 Proportion of films with box office over 100 million yuan in 2018.

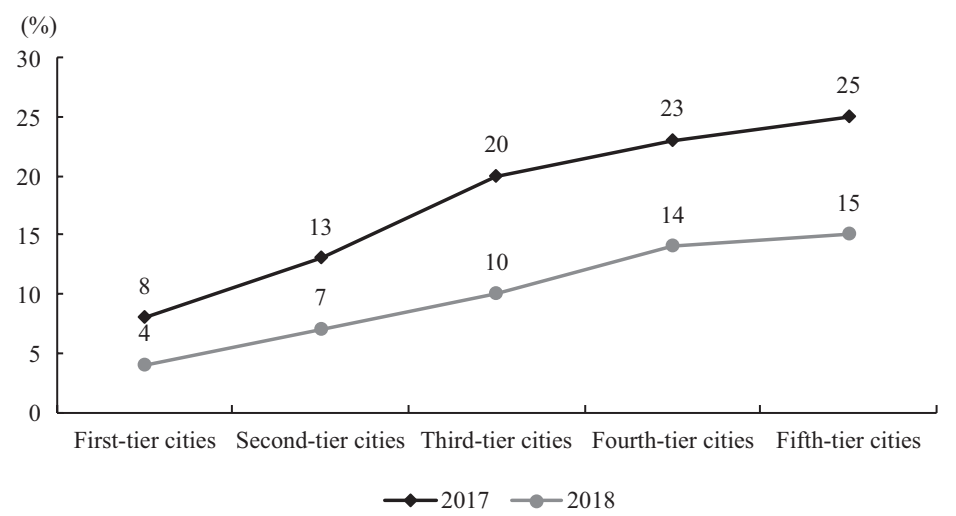

Figure 8.8 A comparative analysis of box office growth rates in first-tier, second-tier, third-tier, fourth-tier and fifth-tier cities in China, 2017-2018.

\section{Analysis of box office from first-tier to fifth-tier cities}

At the city level, the box office growth rate of first-tier and second-tier cities in 2018 is respectively 4 percent and 7 percent, which is lower than the national box office growth rate; the box office growth rates of third-tier, fourth-tier and fifth-tier cities are respectively 10 percent, 14 percent, and 15 percent, which is higher than the national box office growth rate of 9 percent. Especially in the fourth-tier and fifth-tier cities, the box office has increased significantly (Figure 8.8). By putting the first-, second-, and third-tier cities into one group, and then the fourth and fifth tier cities as another group, their box office growth rates are respectively 5.5 percent and 11.6 percent, and the growth rate of box office in the second group is significantly higher than in the first group. 


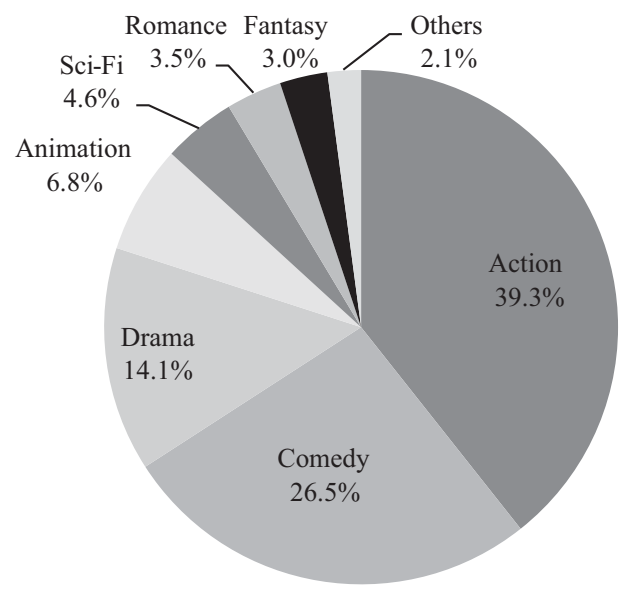

Figure 8.9 Box office distribution of films released nationwide in 2018.

According to the box office ratio, the box office in the third-, fourth- and fifthtier cities accounted for 41.2 percent of the total box office in 2018 which is an increase of 1.4 percentage points over that of 2017. The daily viewing needs of the residents of the cities in the third tier and under still have some room for growth.

\section{The box office distribution of film genres}

Regarding the different genres of films released in 2018, action, comedy, and drama films are ranked the top three at the box office with a ratio of 39.3 percent, 26.5 percent and 14.1 percent. Other genres such as animation, science fiction, romance, fantasy, etc. accounted respectively for 6.8 percent, 4.6 percent, 3.5 percent and 3.0 percent (Figure 8.9). The distribution of different genres of films is clear, and animation, sci-fi and other genres are obviously low in the market. At the same time, from the perspective of geographical distribution, audiences' viewing preferences are also quite different. The audiences of first-tier and second-tier cities prefer drama films, and the audiences of third-tier, fourth-tier, and fifth-tier cities prefer watching romance films.

\section{Analysis of the Chinese film industry production chain in $\mathbf{2 0 1 8}$}

The broad film industry production chain refers to the sum of original creation, film investment and financing, production, distribution, cinema, film derivatives and other film screening channels, which fully reflects the 


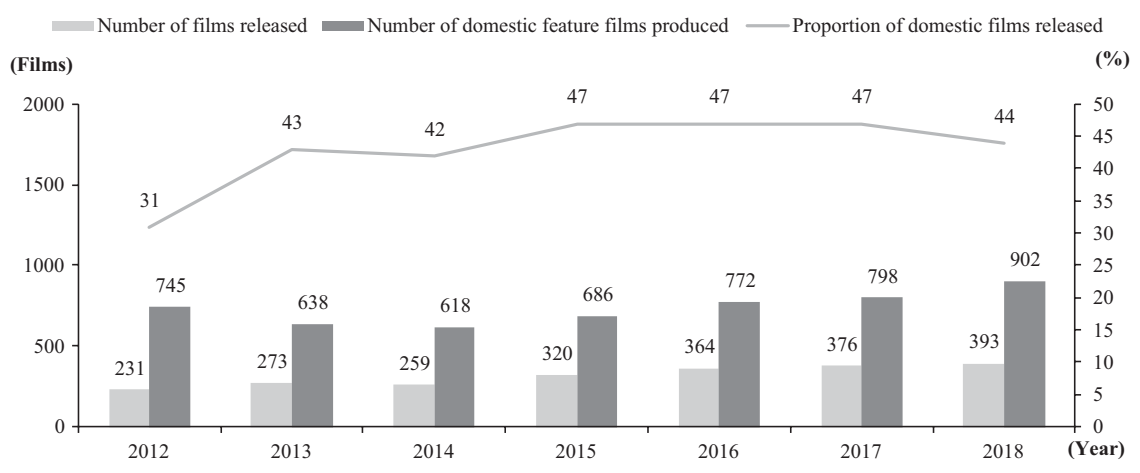

Figure 8.10 A comparison of the release rates of domestic feature films, 2012-2018.

relationship between the various aspects of the film industry's ecosystem. In the narrow sense, the film industry chain in the traditional sense refers to the integrated process of film production, distribution, and screening (this is the "produce-issue-release" procedure). This chapter interprets the 2018 Chinese film market from the perspective of the narrow film industry chain.

\section{Production analysis}

\section{Production creation analysis}

In 2018, China produced 902 feature films, 51 animated films, 61 science fiction films, 57 documentary films, and 11 special films, totaling 1,082. Of the 902 feature films produced in 2018, only 393 were screened in the theater with a 44 percent release rate, which is 3 percentage points lower than the 2017 release rate (Figure 8.10). Since 2014, the number of feature films produced in China has continued to increase, while the online screening rate has declined. There is a serious waste of resources caused by blind investment.

\section{Analysis of the films made by domestic filmmakers}

In 2018, Dying to Survive, Detective Chinatown II, The Island and a large number of excellent domestic films achieved great performance at the box office and also by word of mouth. The audiences highly praised the domestically produced films that are innovative. In contrast, films such as Ashulu and Ipartment are star-studded and costly, but their reputation and box office performance are unsatisfactory. It can be seen that high-quality domestic films are increasingly recognized by the market, and Chinese film audiences and filmmakers have become more mature and rational in terms 
Table 8.22018 box office of top 20 new directors’ film list ( $¥ 100$ million)

\begin{tabular}{|c|c|c|c|c|c|c|}
\hline Number & Name & Type & Director & Release date & $\begin{array}{l}\text { Box } \\
\text { office }\end{array}$ & Score \\
\hline 1 & $\begin{array}{l}\text { Detective } \\
\quad \text { Chinatown II }\end{array}$ & Comedy & $\begin{array}{l}\text { Chen } \\
\text { Sicheng }\end{array}$ & February 16 & 34.0 & 9.0 \\
\hline 2 & Dying to Survive & Feature & Wen Muye & July 5 & 31.0 & 9.6 \\
\hline 3 & $\begin{array}{l}\text { Hello, Mr. } \\
\quad \text { Billionaire }\end{array}$ & Comedy & $\begin{array}{l}\text { Yan Fei, } \\
\text { Peng } \\
\text { Damo }\end{array}$ & July 27 & 25.5 & 9.2 \\
\hline 4 & Us and Them & Love & Liu Ruoying & April 28 & 13.6 & 8.3 \\
\hline 5 & The Island & Comedy & Huang Bo & August 10 & 13.5 & 8.3 \\
\hline 6 & $\begin{array}{l}\text { How Long Will } \\
\text { I Love You? }\end{array}$ & Fantasy & Su Lun & May 18 & 9.0 & 8.7 \\
\hline 7 & A Cool Fish & Feature & Rao Xiaozhi & November 16 & 7.9 & 9.1 \\
\hline 8 & Forever Young & Feature & Li Fangfang & January 12 & 7.5 & 8.6 \\
\hline
\end{tabular}

Source: Mao Yan data.

of film appreciation and film production. This will attract more talent and capital to concentrate on the production of high-quality domestic films. These excellent films will bring more recognitions, thus eventually forming a virtuous circle which will enhance the level of Chinese filmmaking and appreciation.

Behind the 60 billion yuan box office record in 2018, a group of new directors rapidly emerged. Among the top 20 box office films in 2018, the new directors' films contributed 40 percent to the box office (Table 8.2)., There are a lot of new directors, such as Wen Muye, Su Lun, Huang Bo and Liu Ruoying, who were actors and singers turned directors. There are also young directors, such as Yan Fei, Peng Damo and Rao Xiaozhi, who emerged on the market. These "new power" directors are the foundation and driving force for the sustainable development of the film market and are gradually becoming the backbone of the Chinese film market.

In order to tell Chinese national stories, literary adaptation films and television programs of high production quality with positive energy are highly encouraged. The government also aims to promote the rapid and efficient development of the cultural industry, and help the newcomers to be successful. The film channels and a number of literary organizations and the press have jointly established the "Excellent Project" program. On December 23, 2018, the "Excellent Project" program press conference was held in Beijing, and the first batch of six intentional cooperation projects such as Hello 30, Shenzhen Road and School Defence War were officially announced. The "Excellent Project" program will integrate domestic high-quality resources, break down barriers between various links in the film industry chain and supply and demand, and provide many talented young screenwriters, directors and actors with the opportunity to realize their cinematic dreams. 


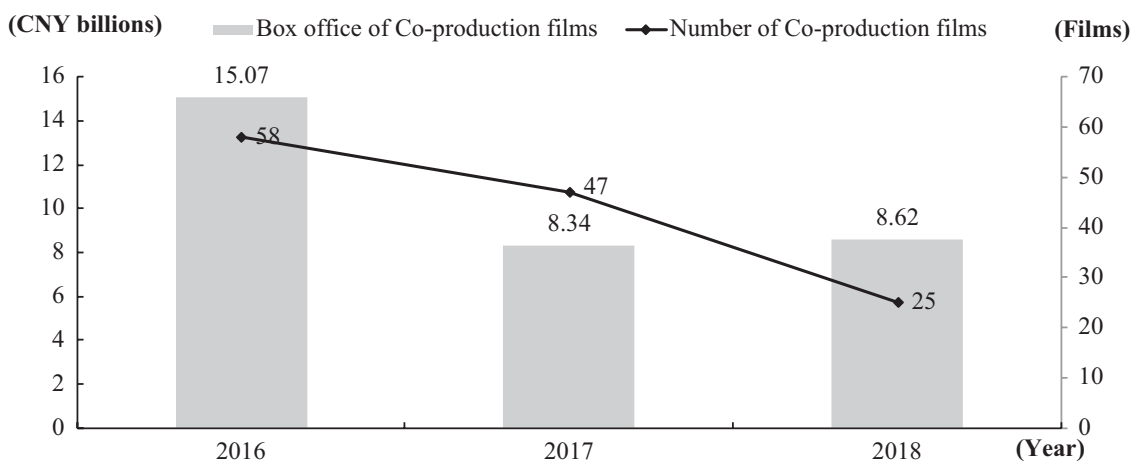

Figure 8.11 Number and box office of Chinese and foreign co-productions, 2016-2018.

\section{Analysis of Chinese and foreign co-productions}

Co-productions refer to a form of cooperation in which domestic and foreign production companies jointly produce films by sharing copyright, benefits and risks. Once they have had a good film review, the Chinese and foreign co-productions can enjoy the same benefits as domestic films enjoy, and gain more advantages in the film production, and sub-accounting, etc. which effectively reduces investment risks. Film labor, investment and other resources are jointly provided by China and a film's co-production country for film production.

In 1939, the first co-production documentary The 400 Million was born. In 1958, Sino-French co-produced their first feature film, Kite. In 1979, the China Film Cooperative Production Company was established. Since then, Chinese and foreign co-productions have entered a new phase of comprehensive cooperation. As China becomes the world's second largest film market, and the quality of filmmaking continues to improve, more countries and regions hope to cooperate with China. By December 31, 2017, China had signed co-production film agreements with 20 governments, including the United States, India, France, Singapore and South Korea. In May 2018, China and Japan signed a co-production film agreement, and the numbers of Chinese and foreign co-productions continued to increase.

In recent years, due to cultural differences, language barriers and other factors, the number of co-productions in China has declined (Figure 8.11). From 2016 to 2018, the number of Chinese and foreign co-productions was respectively 58,47 and 25 , with box office of 15.07 billion yuan, 8.34 billion yuan and 8.62 billion yuan respectively. The average single-part co-production box office was 260 million yuan, 180 million yuan, and 345 million yuan respectively. In 2018, the Chinese and foreign co-production single box office achieved a new leap. 
At present, more Chinese young people are choosing to study filmmaking in Europe and the United States. In future, no matter whether they choose to return to China or continue to stay in the West for filmmaking, they will be the main force of Chinese and foreign co-productions. For Chinese and foreign co-productions, the age of the film crew appears to be getting younger.

\section{Market analysis}

The increase at the box office shows more high-quality films in the market. In addition, deepening the market and enhancing the effective connection between the film and the audience cannot be underestimated. In 2018, in addition to continuing to use traditional announcements, such as press conferences, business cooperation, and roadshows, the Internet has become the core of the Chinese film market. It uses the online booking platform for ticket replenishment, pre-sales, cross-border marketing, etc. to achieve accurate matching and maximum dissemination of film content. Thus, the use of Internet technology provides a better service to producers, theaters and movie viewers. Under the strong promotion of the Internet, on New Year's Eve 2018, the box office broke the single-day box office record in terms of one individual country box office in a global film market. The audience numbers also broke the single-day cinema admission record.

In 2018, the Chinese film market was further transformed and upgraded based on online and offline integration, mainly in the following three respects: (1) expansion of publicity channels and exploration of new consumer groups; (2) extension of marketing depth for full marketing connections; and (3) cross-border high-frequency industry to achieve leapfrogging.

\section{Analysis of cinema and the cinema market}

\section{Cinema market analysis}

In 2018, the top three, top five, and top ten city theater box office outlets in China were respectively 19 billion yuan, 28 billion yuan, and 41.7 billion yuan, with box office ratios of 31.3 percent, 46.1 percent, and 68.7 percent, respectively. The concentration of cinemas in the year increased slightly. The top three theaters in the box office are: Wanda Cinema ( 81.88 billion yuan), Dadi Cinema (6.05 billion yuan) and Shanghai Lianhe Cinema (4.84 billion yuan) (Table 8.3).

By December 31, 2018, there were 48 city theaters in China, of which 40 theaters have exceeded 100 million yuan, which is one theater more than in 2017. In 2018, there were 17 theaters in China with annual box office exceeding 1 billion yuan, which was the same as in 2017. There were 23 theaters with annual box office of 100 million to 1 billion yuan, which is one more than the same period of the previous year; the annual box office was below 100 million yuan of nine theaters, one less than the same period of the previous year. 
Table 8.3 List of the top 10 city theaters in China in 2018

\begin{tabular}{llllll}
\hline Rank & Theater name & $\begin{array}{l}\text { Box office } \\
\text { (100 million } \\
\text { yuan) }\end{array}$ & $\begin{array}{l}\text { Sessions (ten } \\
\text { thousand } \\
\text { times) }\end{array}$ & $\begin{array}{l}\text { Number } \\
\text { of people } \\
\text { (millions) }\end{array}$ & $\begin{array}{l}\text { Attendance } \\
\text { rate (\%) }\end{array}$ \\
\hline 1 & Wanda & 82 & 944 & 200 & 13.47 \\
2 & Dadi & 60 & 1160 & 178 & 12.14 \\
3 & Shanghai Lianhe & 48 & 668 & 130 & 13.89 \\
4 & Zhong Ying & 45 & 849 & 129 & 12.8 \\
& $\quad$ Nanfang & & & & \\
& $\quad$ Singanxian & & 946 & 130 & 10.66 \\
5 & ZhongYing Digital & 44 & 609 & 109 & 13.95 \\
6 & ZhongYing Xingmei & 39 & 463 & 83 & 12 \\
7 & GZ. Jinyi Zhujiang & 30 & 507 & 79 & 11.55 \\
8 & HG & 26 & 428 & 62 & 11.36 \\
9 & Hua Xia Lianhe & 21 & 344 & 60 & 13.47 \\
10 & Jiangsu Omnijoi & 21 & &
\end{tabular}

Source: EN Film Think Tank.

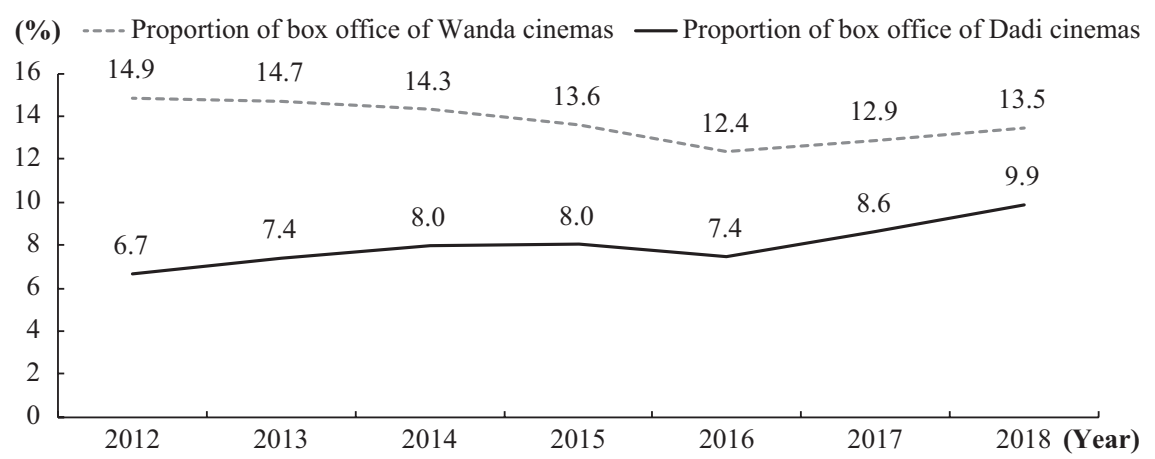

Figure 8.12 Proportion of the box office of Wanda Cinemas and Dadi Cinemas, 2012-2018.

Since 2012, the proportion of box office in Wanda Cinema has always ranked first in the country and has constantly remained above 12 percent and even reached its highest point at 14.9 percent. Due to the rapid growth of other cinemas, the proportion of box office in Wanda Cinema has been declining, and the gap with the second cinema line has been narrowing from 8.2 percentage points in 2012 to 3.6 percentage points in 2018 (Figure 8.12)

From 2014 to 2018, the number of new cinemas in China was respectively $1,106,1,574,1,412,1,430$, and 1,143, with growth rates of 22 percent, 24 percent, 18 percent, 15 percent, and 11 percent (Figure 8.13). In 2018, China built 1,143 new cinemas with a growth rate of 11 percent, which is 2 percentage 


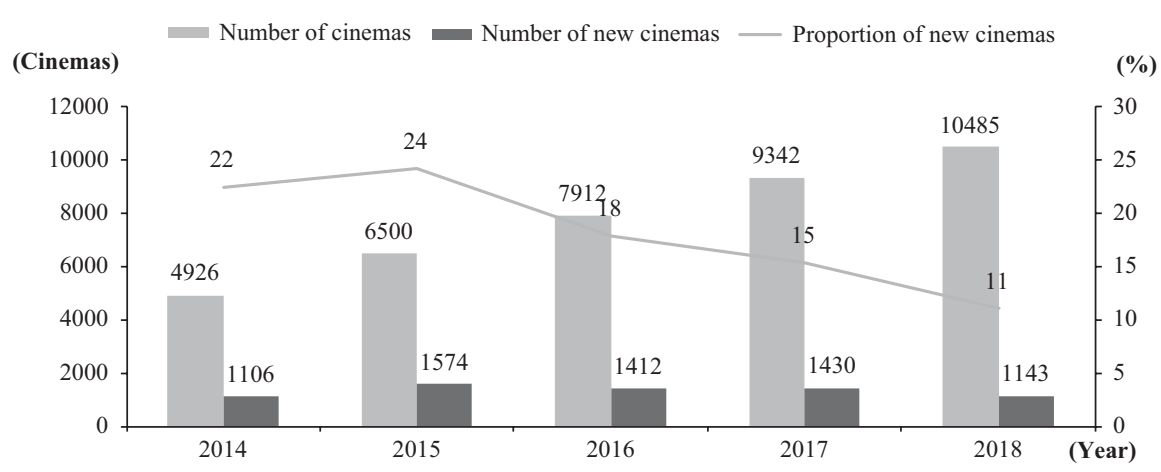

Figure 8.13 Total number of cinemas, the increase in number and the proportion of new cinemas in China, 2014-2018.

points higher than the annual box office growth rate ( 9 percent). The situation of oversupply led to a lower cinema admission rate (11 percent) and a single screen output (1.01 million yuan), which was a state of serious overcapacity reaching its lowest level since 2014.

In all aspects of the Chinese film industry chain, the corresponding income is mainly obtained through box office accounts. According to industry practice, the theater generally receives 50 percent of the box office income. The rank of the movie box office is directly related to the income of the theater. The top ten theaters in the box office in 2018 are Jackie Chan's Beijing Yaolai (799.20 million yuan), Jinyi Beijing Joy City IMAX store (69.6 million yuan), and Guangzhou Feiyang Studios (Zhengjia Branch) (68.2 million yuan), etc. (Table 8.4). Among the top ten theaters in the box office, Beijing accounts for 50 percent; Shanghai accounts for 20 percent; Guangzhou accounts for 10 percent; Wuhan accounts for 10 percent; and Nanjing accounts for 10 percent.

From 2014 to 2018, the annual growth rate of the number of screens was respectively $5,397,8,035,9,552,9,597$, and 9,303, with growth rates of 30 percent, 34 percent, 30 percent, 23 percent, and 18 percent respectively (Figure 8.14). Although the annual growth rate of screens has decreased from 2015 , it is still much higher than the annual box office growth rate (9 percent). From 2014 to 2018, each screen output was respectively 1.25 million yuan, 1.39 million yuan, 1.11 million yuan, 1.1 million yuan and 1.01 million yuan. In 2018, the single-screen output reached a five-year low.

\section{Online ticket market analyses}

\section{Online ticketing platform business model}

The online ticketing platform has emerged from the "Low-cost Movie Ticket Group Purchase War" launched in 2010 by the "Sankuai Online" and "Baidu 
Table 8.4 Top 10 cinema chains in China's movie box office in 2018

\begin{tabular}{|c|c|c|c|c|c|}
\hline Rank & Cinema chain & $\begin{array}{l}\text { Box office } \\
\text { (ten } \\
\text { thousand } \\
\text { yuan) }\end{array}$ & $\begin{array}{l}\text { Number } \\
\text { of people } \\
\text { (10,000 } \\
\text { people) }\end{array}$ & $\begin{array}{l}\text { Price } \\
\text { (yuan) }\end{array}$ & $\begin{array}{l}\text { Attendance } \\
\text { rate }(\%)\end{array}$ \\
\hline 1 & Jackie Chan Beijing Yaolai & 7992 & 178 & 45 & 22.60 \\
\hline 2 & $\begin{array}{l}\text { Jinyi Cinema Beijing Joy } \\
\text { City IMAX }\end{array}$ & 6960 & 103 & 67 & 31.10 \\
\hline 3 & $\begin{array}{l}\text { Guangzhou Feiyang } \\
\text { Cinema(ZhengJia } \\
\text { branch) }\end{array}$ & 6820 & 121 & 56 & 24.70 \\
\hline 4 & Capital Cinema, Xidan & 6347 & 115 & 55 & 28.00 \\
\hline 5 & $\begin{array}{l}\text { UME Cinema (Beijing } \\
\text { Shuang Jing) }\end{array}$ & 5590 & 89 & 63 & 23.80 \\
\hline 6 & Nanjing Xinjiekou Cinema & 5523 & 139 & 41 & 26.90 \\
\hline 7 & $\begin{array}{l}\text { Shanghai Bailigong } \\
\text { (Huanmao iapm) }\end{array}$ & 5477 & 69.8 & 79 & 29.30 \\
\hline 8 & $\begin{array}{l}\text { Wushangmoer International } \\
\text { Cinema }\end{array}$ & 5423 & 159 & 34 & 26.40 \\
\hline 9 & $\begin{array}{l}\text { Lumière Beijing Changyi } \\
\text { Tianjin IMAX Studios }\end{array}$ & 5322 & 93 & 57 & 20.00 \\
\hline 10 & $\begin{array}{l}\text { Shanghai Wujiaochang } \\
\text { Wana Cinema }\end{array}$ & 5348 & 91 & 57 & 20.70 \\
\hline
\end{tabular}

Source: EN Film Think Tank.

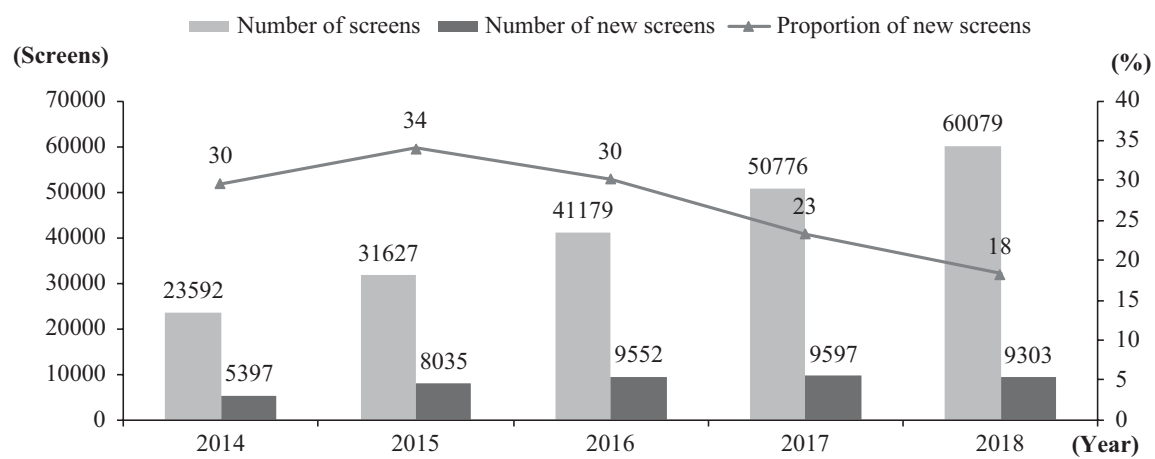

Figure 8.14 Total number and the increase in and growth rate of Chinese screens, 2014-2018

Nuomi." The online ticketing platform, with its ticket sales as a breakthrough, continues to expand both upstream and downstream of the film industry chain, and has become a comprehensive platform covering production, promotion, ticket sales, and sales of derivatives, etc. (Figure 8.15). 


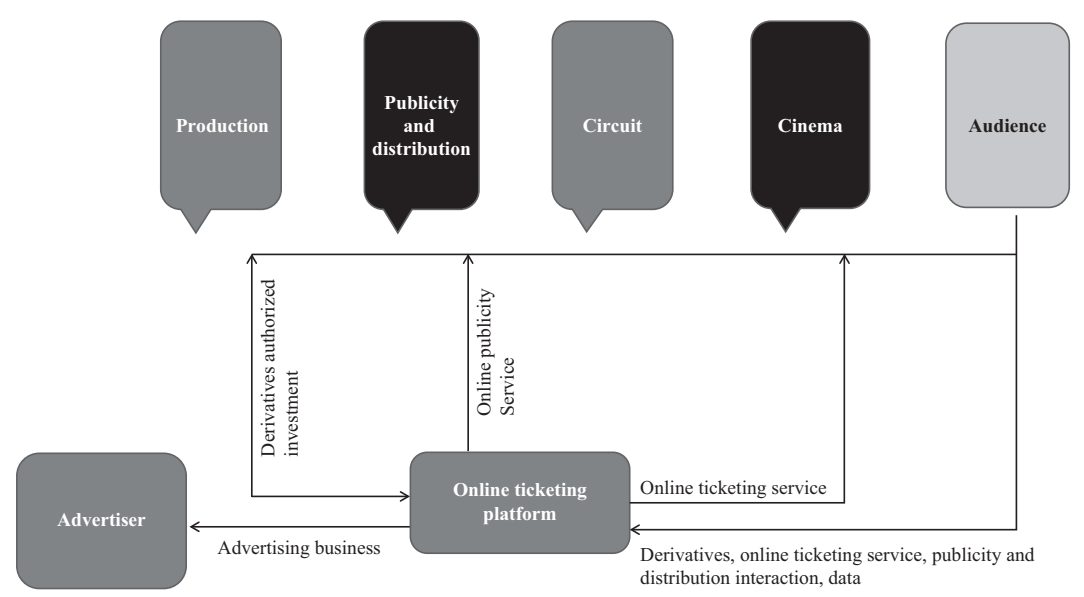

Figure 8.15 Online ticketing platform business model.

The main source of income for the online ticketing platform is the movie ticket sales revenue. For each movie ticket sold, the online ticketing platform charges a fee of about 3 percent of the entry price. The system service provider charges a further fee of about 3 percent of the fee to provide the ticket. The ticket collection machine charges a further fee of about 4 percent of the entry price (Table 8.5 ).

The second largest source of revenue for online ticketing platforms is investment production and distribution. The ticketing data and user data accumulated by the Internet giant behind the online ticketing platform attract more and more investors to use the platform to accurately announce a film. In addition to deepening the film distribution market, the online ticketing platform also selects quality projects for investment. The online ticketing platform participated in the production and distribution of the top five films of the 2018 domestic box office at different levels (Table 8.6).

The lowest percentage of online ticketing platform revenue is advertising services and derivatives sales. In terms of advertising services, in addition to the common types of banner advertisements and screen advertisements, the online ticketing platform also gives full play to its advantages to provide new forms of advertisements, such as logos, etc. In terms of derivatives sales, the online ticketing platform provides online link authorization, promotion, sales and other full-link services by partnering with relevant parties.

The United States and Japan are the main Internet Protocol (IP) sources for global film derivatives. The experience of the United States and Japan shows that when the per capita gross national income (GNI) is around US\$10,000, the film derivative IP takes off. For example, when Star Wars was released in 1977, the average American GNI was US\$9610. When the per capita GNI reaches about US $\$ 30,000$, there will be a massive development of derivatives 
Table 8.5 Online ticketing fee sharing mode (\%)

\begin{tabular}{lll}
\hline Cost category & $\begin{array}{l}\text { Proportion } \\
\text { of price }\end{array}$ & Service provided \\
\hline $\begin{array}{l}\text { System service provider } \\
\text { interface fee }\end{array}$ & 3 & $\begin{array}{c}\text { Provide system services (currently, the } \\
\text { TaoPiaopiao uses the Yueke Fenghuang } \\
\text { Jiaying system, and other ticketing } \\
\text { platforms are provided by third-party } \\
\text { service providers) }\end{array}$ \\
$\begin{array}{l}\text { Online ticketing } \\
\text { added fee }\end{array}$ & 3 & $\begin{array}{l}\text { Online ticketing service } \\
\text { Ticket collection fee }\end{array}$ \\
Total & 4 & $\begin{array}{c}\text { Provide ticket collection machine to pick up } \\
\text { tickets }\end{array}$ \\
\hline
\end{tabular}

Source: CITIC Securities.

Table 8.6 The main investment and distribution of the online ticketing platform in 2018 ( 100 million)

\begin{tabular}{|c|c|c|c|c|c|}
\hline Number & Movie title & Release date & $\begin{array}{l}\text { Box } \\
\text { office }\end{array}$ & Ali role & Enlight role \\
\hline 1 & $\begin{array}{l}\text { Operation } \\
\quad \text { Red Sea }\end{array}$ & February 16 & 36.5 & $\begin{array}{l}\text { Al co-produced, } \\
\text { Tao Piaopiao } \\
\text { joint issue }\end{array}$ & $\begin{array}{l}\text { MaoYan and } \\
\text { WeiYing } \\
\text { co-produced }\end{array}$ \\
\hline 2 & $\begin{array}{l}\text { Detective } \\
\text { Chinatown } \\
\text { II }\end{array}$ & February 16 & 34.0 & $\begin{array}{l}\text { Tao Piaopiao } \\
\text { joint issue }\end{array}$ & $\begin{array}{l}\text { Youth and Eight } \\
\text { co-produced }\end{array}$ \\
\hline 3 & $\begin{array}{l}\text { Dying to } \\
\text { Survive }\end{array}$ & July 5th & 31.0 & $\begin{array}{l}\text { Al co-produced, } \\
\text { Tao Piaopiao } \\
\text { joint issue }\end{array}$ & $\begin{array}{l}\text { MaoYan and } \\
\text { WeiYing } \\
\text { co-produced }\end{array}$ \\
\hline 4 & $\begin{array}{l}\text { Hello, Mr. } \\
\quad \text { Billionaire }\end{array}$ & July 27 & 25.5 & $\begin{array}{l}\text { Al co-produced, } \\
\text { Tao Piaopiao } \\
\text { joint issue }\end{array}$ & $\begin{array}{l}\text { MaoYan and } \\
\text { WeiYing } \\
\text { co-produced }\end{array}$ \\
\hline 5 & $\begin{array}{l}\text { Monster } \\
\text { Hunt } 2\end{array}$ & February 16 & 22.4 & $\begin{array}{l}\text { Tao Piaopiao } \\
\text { produced }\end{array}$ & $\begin{array}{l}\text { MaoYan and } \\
\text { WeiYing } \\
\text { mainly } \\
\text { co-produced }\end{array}$ \\
\hline
\end{tabular}

Source: MaoYan Data, CITIC Securities.

IP in film and television. When the Chi-bi Maruko released the theater version in 1990 , the Japanese per capita GNI was US\$27,850. Based on a compound growth rate of 6 percent, China's per capita GNI will exceed US $\$ 10,000$ in 2020, and per capita GNI will exceed US\$30,000 in 2040. The domestic derivatives IP will gradually be made into film and television projects, and the proportion of revenue will gradually increase. 


\section{Shuzhen Sun}

Table 8.7 Development stages of China's online ticketing platform

\begin{tabular}{lll}
\hline Date & Stage & Development path \\
\hline 2010-2012 & $\begin{array}{c}\text { Growth } \\
\text { period } \\
\text { Development } \\
\text { period } \\
\text { 2013-2016 } \\
\text { 2017-present } \\
\text { period }\end{array}$ & $\begin{array}{c}\text { Expanding the scope of cooperation with cinemas } \\
\text { and generating an online-based business model } \\
\text { Ticket supplement, infiltration upstream and } \\
\text { downstream of the industrial chain } \\
\text { Stable competition pattern, explore profit model } \\
\text { through differentiated management }\end{array}$ \\
\hline
\end{tabular}

Source: Speedway Institute.

\section{The development stage of the online ticketing platform}

In 2010, with the introduction of the online selection service by Guevara Life Net, the online ticketing business model started operations in China. Later, with the rise of online payments and advances in Internet technology, use of online ticketing platforms has risen rapidly (Table 8.7).

\section{Toward a standardized and rational Chinese film industry}

In 2018, the middle and lower sectors of the Chinese film industry chain added incremental value to the industry. The State Press, Publication, Radio, Film and Television Administration changed its name to The National Film Board and was directly controlled by the Central Publicity Department, which reflected an increasing focus by the Party and the government on the Chinese film industry. Audiences also paid more attention to films' reputation, and the viewing preferences became more rational. Different kinds of films became popular in the market, with a realist film Dying to Survive gaining audience's special preference. The quality of domestic films increased substantially, and their box office exceeded that of imported films. The film market share of the top ten films at the box office reached 68.7 percent, and the market concentration further improved. The online ticketing platform shifted its focus by covering the ticketing business in the entire film industry chain. The positive trend displayed by all parties in the industry has enabled the Chinese film industry to enter a new stage of healthy development in which high-quality films are constantly being produced and the film industry's structure also tends to be rational.

\section{The government's view: the national will to promote the development} of the film industry

On March 21, 2018, the Central Committee of the Communist Party of China issued the "Deepening Party and State Institutional Reform Plan." The plan decided to change the name of the film board affiliated to the 
State Administration of Press, Publication, Radio, Film and Television to "The National Film Board," and it is controlled by the Central Publicity Department. The aim is to bring about the unified management of film production. The promotion of the regulatory authorities means that the country will encourage cinema among the public and strive to make the Chinese national cinema an important carrier for exporting the core values of the country and open up a new window for future development of the film industry.

The film industry policy introduced in recent years (Table 8.8) shows that the country has been actively deploying film industry channel arrangements, industry standardization and film exports overseas.

\section{The content: the quality of domestic films improved and became the main growth driver at the box office}

In 2018, the box office of domestic films was 36.6 billion yuan, accounting for 60 percent of the total box office, which is an increase of 21 percent compared to that of the same period of the previous year. The box office of imported films was 24.1 billion yuan, accounting for 40 percent, which is a decrease of 6 percent compared to that of the same period of the previous year. At the same time, in 2018, there were 8 domestic films with box office exceeding 1 billion yuan, and 19 domestic films with box office exceeding 500 million yuan. With this excellent market performance, domestic films have maintained their box office advantage over imported films since 2013.

The statistical analysis of the 30 "MaoYan Movie Scores" of the domestic box office between 2015 and 2018 is shown in Figure 8.16. From the "MaoYan Movie" audiences rating, there are 11 excellent films with a score of greater than or equal to 9.0 in 2018, accounting for 37 percent; and 14 middle-level movies with a score of 8.0-9.0, accounting for 47 percent. At 7.9, there were three middle and lower-level films, accounting for 10 percent. The scores of less than 7.0 were considered to be "poor quality" films, accounting for 7 percent. Compared with the "MaoYan Movie", the "Douban" audience score is much stricter. Dying to Survive was the only domestic movie with a score of 9 points on the "Douban" users' rating since 2015.

In 2016, there were seven excellent domestic films with a "Mao Yan" user score of 9.0 or higher, accounting for 23 percent; six domestic and foreign language films with a score of 7.0-7.9 points, accounting for 20 percent. The overall quality of domestic films in 2016 was low, which was in line with the poor box office in 2016. In order to meet the increasing aesthetic taste of the audiences, domestic production companies responded positively. After 2016, the overall quality of domestic films continued to improve, and finally achieved excellent market performance in 2018. At the same time, with the release of government policies to explicitly limit the proportion of film stars' remuneration over the total budget of a film, the focus of film costs transferred from paying the stars to the production of the film itself, which resulted in an improvement in the quality of the films. 


\section{Shuzhen Sun}

Table 8.8 Major film industry policies promulgated, 2012-2018

\begin{tabular}{|c|c|c|}
\hline Date & Policy title & Main content \\
\hline $\begin{array}{l}\text { November } \\
2012\end{array}$ & $\begin{array}{l}\text { Notice on } \\
\text { Subsidizing the } \\
\text { Creation and } \\
\text { Production of } \\
\text { Domestic High- } \\
\text { tech Format } \\
\text { Films }\end{array}$ & $\begin{array}{l}\text { If the box office revenue is } 300 \text { million yuan } \\
\text { (inclusive) to } 500 \text { million yuan in high-tech } \\
\text { format films, then the rewarding support fund } \\
\text { will be } 5 \text { million yuan; if the box office income } \\
\text { is more than } 500 \text { million yuan (inclusive), then } \\
\text { the incentive support fund will be } 10 \text { million } \\
\text { yuan }\end{array}$ \\
\hline $\begin{array}{c}\text { January } \\
2013\end{array}$ & $\begin{array}{l}\text { Current } \\
\text { Measures for } \\
\text { Strengthening } \\
\text { the Management } \\
\text { of Film } \\
\text { Cooperation } \\
\text { across the } \\
\text { Taiwan Straits }\end{array}$ & $\begin{array}{l}\text { Taiwanese films that obtained a film release } \\
\text { license were released as imported films on the } \\
\text { mainland. Films co-produced by the mainland } \\
\text { and Taiwan enjoy domestic film-related } \\
\text { treatment on the mainland }\end{array}$ \\
\hline June 2014 & $\begin{array}{l}\text { Notice on } \\
\text { Supporting } \\
\text { Several } \\
\text { Economic } \\
\text { Policies for Film } \\
\text { Development }\end{array}$ & $\begin{array}{l}\text { The state promotes tax incentives and financial } \\
\text { support for the film industry, and sells film } \\
\text { copies and transfers of copyrights to film } \\
\text { companies. From January } 1,2014 \text { to December } \\
\text { 31, 2018, VAT is exempted. }\end{array}$ \\
\hline $\begin{array}{r}\text { March } \\
2016\end{array}$ & $\begin{array}{l}\text { Notice on } \\
\text { Rewarding } \\
\text { Overseas } \\
\text { Promotion } \\
\text { of Excellent } \\
\text { Domestic Films }\end{array}$ & $\begin{array}{l}\text { If the domestic box office revenue of a domestic } \\
\text { film reaches or exceeds } 1 \text { million yuan, there } \\
\text { will be rewards. }\end{array}$ \\
\hline July 2016 & $\begin{array}{l}\text { Law of the People's } \\
\text { Republic of } \\
\text { China on } \\
\text { Film Industry } \\
\text { Promotion }\end{array}$ & $\begin{array}{l}\text { Detailed provisions for film creation, filming, } \\
\text { distribution, screening, and legal liability }\end{array}$ \\
\hline $\begin{array}{c}\text { December } \\
2017\end{array}$ & $\begin{array}{l}\text { Notice on } \\
\text { Rewarding the } \\
\text { Screening of } \\
\text { Domestic Films } \\
\text { and Highlighting } \\
\text { Cinemas }\end{array}$ & $\begin{array}{l}\text { If the domestic film screening annual revenue } \\
\text { accounts for more than } 55 \text { percent of the } \\
\text { total income, and meets the reward conditions } \\
\text { stipulated in the Notice, then it is awarded in } \\
\text { three grades }\end{array}$ \\
\hline $\begin{array}{c}\text { October } \\
2018\end{array}$ & $\begin{array}{l}\text { Notice on Further } \\
\text { Regulating the } \\
\text { Work Related to } \\
\text { Taxation Order } \\
\text { in the Film } \\
\text { and Television } \\
\text { Industry }\end{array}$ & $\begin{array}{l}\text { From October } 2018 \text { to June 2019, in accordance } \\
\text { with self-examination, self-correction, } \\
\text { supervision and correction, key inspection, } \\
\text { summary and improvement principles, further } \\
\text { standardizing of the taxation work of the film } \\
\text { and television industry }\end{array}$ \\
\hline
\end{tabular}




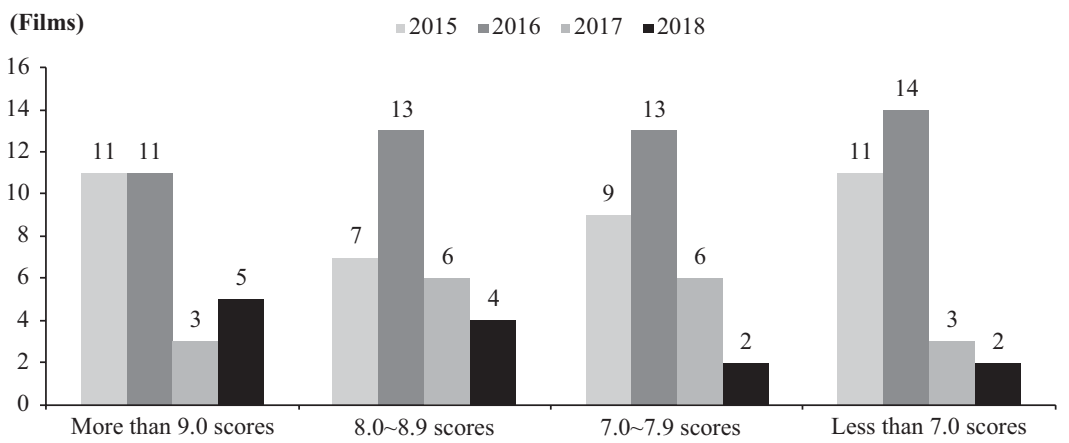

Figure 8.16 A statistical analysis of the top 30 "MaoYan" scores of domestic films in the box office, 2015-2018.

\section{Audiences: the numbers increased}

In 2018, the increase in the audience numbers for films in China is reflected in two ways: first, audience numbers are increasing generously across the board; second, the number of regular frequent moviegoers is increasing. With the increase in income and living standards, the age group of film audiences has also expanded, and more young and middle-aged people are becoming regular moviegoers. The "Mao Yan" data show that the proportion of audiences over the age of 30 increased from 38.3 percent in 2017 to 41.7 percent in 2018 which is an increase of 3.4 percentage points. At the same time, regarding the frequency of viewing, the number of viewers in 2018 decreased from 46.6 percent in 2017 to 44.8 percent in 2018 , which is a drop of 1.8 percentage points. The number of viewers who went to the movies between 2 and 11 times increased from 50 percent in 2017 to 51.5 percent in 2018, which is an increase of 1.5 percentage points. The number of viewers who watched 12 or more movies increased from 3.4 percent in 2017 to 3.8 percent in 2018, which is an increase of 0.4 percent.

In 2018, the aesthetic taste of Chinese audiences improved significantly, and the quality of films continuously influenced the audience's decisions to view films. Among the many domestic films released, Operation Red Sea and Project Gutenberg are typical films that achieved box office success through positive word of mouth. On the opening day of Operation Red Sea (February $16,2018)$, its box office was only 130 million yuan, accounting for 3.5 percent of the total box office. But high public praise (a "Douban" score of 9.0) made the follow-up box office rise. The box office of Operation Red Sea steadily rose for six consecutive days, eventually reaching a total box office of 3.65 billion yuan, ranking first at the 2018 Chinese movie box office. Project Gutenberg has a total box office of about 1.27 billion yuan, ranking 13th at the box office in 2018, but on its opening day in theaters (September 30,2018), its box office 
was also poor with only 54.82 million yuan. Following good opinions of it among the public (a "Douban" Rating of 8.2) six days after its release, the daily box office was basically stable at 90 million yuan.

\section{Channels: relatively excessive production capacity and industry concentration continue to increase}

The top ten cities achieved box office of 41.7 billion yuan, accounting for 68.7 percent, which was slightly higher than the box office ( 37.8 billion yuan) and box office ratio ( 68 percent) in 2017. The film market concentration further improved.

The size of the bargaining power of the cinema in the industry chain is determined by the strength of the final screening channels it owns. Generally speaking, the more final projection channels a cinema chain has, the more bargaining power it possesses. At present, in addition to China United, the other nine of the top ten cinema chains in China have been listed and have strong financial advantages. At the same time, according to statistics produced by the American Film Institute, the market share of the three mainstream cinemas in North America in 2017 was around 50 percent.

Driven by international practices and self-interest, China's cinemas have sufficient room for integration, and strong, well-funded theater companies will continue to acquire cinemas to promote industry concentration and overall operational efficiency. At the same time, smaller theaters have a stronger willingness to integrate in order to reduce costs and change the single profit model.

In 2018, the number of Chinese cinema screens totaled 60,079, which is an increase of 18 percent compared to that of the same period of the previous year. The growth rate of cinema screens exceeded that of the box office $(9$ percent) and that of the number of moviegoers (6 percent). As a result, the singlescreen output and the average cinema admission rate continued to decline. At the same time, in 2018, China's single-screen viewings fell to 28,600, which is a decrease of 10 percent compared to that of the same period of the previous year. Single-screen output was 1.01 million yuan, which is a decrease of 11 percent compared to that of the same period of the previous year. It is expected that more and more theaters and cinemas will be under increasing operational pressure, and cinema integration will become imperative. In future, theaters that meet the expectations of viewers' refined operation requirements after upgrades will become the new focus of cinema development.

\section{Online platforms: the formation of a duopoly pattern and the focus of competition shifts}

Relying on the financial strength of powerful online platforms and the advantage of having the payment tool entrance, the two major platforms "MaoYan" and "Taobao" stand out from the fierce market competition, forming a pattern of "MaoYan" and "TaoPiaopiao" duopoly competition. "TaoPiaopiao" and 
"MaoYan" have already broken free from the endless ticket battle by exploring a new profit model. As the Internet giants in China, they both use the ticketing platform as an important channel for data collection and monetization, and combine their own advantages to rebuild the entertainment ecosystem. The "TaoPiaopiao" is a major component of the listed company, Ali Films. The development strategy has been tilted toward the announcement service. The current development strategy has been revised to "two-wheel drive."

\section{Direction of the Chinese film industry's development}

\section{The content: improvement in quality and structure}

The healthy development of any form of cultural entertainment will need consumers' positive feedback on the quality of the content. High-quality content stimulates consumers to pay, and thus content creators will have sufficient funds and the incentive to develop more high-quality content, which further stimulates consumers' consumption. Films such as Operation Red Sea, Project Gutenberg and other titles gain success through word of mouth, which shows how audiences' positive feedback can result in box office success. In future, more filmmakers will focus on improving the quality of their work. Thus, their projects will speak for themselves to win the market.

Due to the matured window period and the multi-layer distribution system, Hollywood movie box office revenue accounted for only about 25 percent. Copyright revenue from TV, home entertainment and other channels accounted for around 75 percent. The core revenue of China's film content is mainly from the box office revenue share, and the proportion of non-box office income is significantly lower. Compared with box office revenue, channel-side copyright is relatively easy to predict, and an increase in channel-end revenue can reduce the risk of film investment. With respect to slower box office growth, improving the income structure and increasing non-cinema line copyright revenue are the main ways to increase revenue at the film content end in the future.

In November 2016, the film I Am Not Madame Bovary earned a total revenue from the content party of RMB 2.52 million, of which the box office share was 60 percent, and online copyright plus overseas copyright revenue accounted for 34 percent. Movies are one of the core products that video websites use to attract users. As Internet video websites gradually become mainstream channels, there is still room for improvement in the proportion of copyright revenues in China's content market.

\section{Sales channel: the head effect continues to play a role, and the market concentration improved}

From the development experience of the United States, Japan and South Korea, when the number of screens in a country approaches saturation point, the number of screens will remain stable and the number of theaters 
will continue to decrease. The average number of screens in the theater will increase rapidly. Large-scale multiplex cinemas will gradually replace smallscale cinemas, and market concentration will gradually increase. In the United States, for example, the number of screens reached its peak around 2000, and the number of theaters has been steadily decreasing since then.

From the perspective of the number of screens, only the US market can be compared with China in a global context. Based on the development of the industry, the current screen density of Chinese cinemas is close to the peak of the number of US screens from 1998 to 1999. After nearly 20 years of industry development in the United States, the market share of the top three cinemas officially exceeded 50 percent. Compared to the US market, China has more screens and more problems in theater concentration, which will be a long-term process for perhaps more than 20 years.

From the perspective of the development of overseas matured markets, mergers and acquisitions are the main way to increase the concentration of the cinema chain industry. In the Chinese market, as industry competition intensifies, the demand for cinema mergers and acquisitions will gradually increase. Through mergers and acquisitions, the problem of single revenue and operation losses of cinemas can be solved and managed to a certain extent.

In short, to promote the development of the Chinese film industry, on the one hand, it is necessary to improve the quality of the domestic film content, to attract more viewers into the cinema through positive film reviews and word of mouth, and to increase the frequency of audiences' viewing; on the other hand. From the sales channel side, it is necessary to enhance the cinema screening experience in all aspects, such as equipment upgrade, management level, and cinema network brand effect.

\section{Bibliography}

Baidu. Encyclopedia. Available at: http://baike.baidu.com.

Baidu Index. Available at: http://index. baidu.com.

Bin, L., Xingzhen, N. and Zhengshan, L. (2018). Global Film Industry Development Report (2018), Beijing: Social Science Literature Publishing House.

Box Office Mojie. Available at: www.boxofficemojo.com.

China Box Office. Available at: www.cbooo.cn.

China Film Association and China Federation of Literary and Art Film Center (2018). China Film Industry Research Report, Beijing: China Film Press.

China Internet Network Information Center. Available at: www.cnnic net.cn.

Douban Movie Leaderboard. Available at: https://movie.douban.com/chart.

Former State Press, Publication, Radio, Film and Television. Available at: www. sapprft.gov.cn.

Mengnan, X. (2018). On the New Film Law, Legislation Measures and Supervision of the Box Office of the Missing Detective, Audiovisual, No. 1, 36-37.

Ping, Z. (2017). Analysis of New Mainstream Film Marketing in the New Media Environment, Contemporary Film, No. 12, 167-169. 
Shaoyang, L. and Yunyao, M. (2017). Chinese Film: Seiko Production and Connotation Exploration Collaboration, Education Media Research, No. 6, 30-32.

Shuguang, R. and Guanping, W. (2017). Chinese Film: Reflection and Adjustment, Journal of Beijing Film Academy, No. 1, 5-10.

Xie, X. and Donglei, F. (2017). A Preliminary Study on the Evolution of China's Film Industry in the New Media Era, National Art Research, No. 5, 107-112.

Xinru, G. and Shuqin, H. (2017). The Star Effect and the Empirical Study of the Chinese Box Office, Modern Communication (Journal of Communication University of China), No. 12, 120-125.

Yan, C. (2018). China Film Industry Development Trend Report, Beijing: Communication University of China Press. 